\title{
FASILITAS TRANSIT RAWA BUAYA
}

\author{
Cindy Herlim Santosa ${ }^{1)}$, Sidhi Wiguna Teh ${ }^{21}$
}

1) Program Studi S1 Arsitektur, Fakultas Teknik, Universitas Tarumanagara, cindyherlims@gmail.com

2) Program Studi S1 Arsitektur, Fakultas Teknik, Universitas Tarumanagara, sidhi@ft.untar.ac.id

\begin{abstract}
Abstrak
Jakarta merupakan kota kedua terpadat di dunia dengan kepadatan penduduk mencapai 10 juta jiwa pada tahun 2017. Kepadatan menimbulkan perkembangan yang cepat di wilayah Jakarta tanpa adanya perencanaan. Perkembangan yang terjadi membuat batasan antar zonasi perkantoran yang berada di daerah pusat kota dan zona hunian yang berada di pinggir kota. Zona yang terbentuk mengakibatkan peningkatan pergerakan mobilitas yang dapat dilihat dari kepemilikan kendaraan, pengguna moda transportasi, dan kemacetan yang terjadi di Jakarta. Charles Montgomery dalam buku Happy City mengatakan mengenai kemacetan yang tinggi menimbulkan penurunan kesehatan yang terjadi akibat stress bagi kaum komunitas moda transportasi umum. Salah satu cara mengurangi stress adalah dengan bersosialisasi menurut Adhiatma dan Christianto (2019). Third Place atau ruang sosial menjadi solusi untuk bersosialisasi bagi komunitas transportasi umum. Konsep Third Place dapat lebih dirasakan oleh komunitas transportasi umum, dimana mereka dapat merasakan perbedaan zona perumahan dengan zona perkantoran. Tempat transit atau tempat singgah yang terbentuk akan menjadi ruang sosial yang digunakan tanpa membedakan status sosial. Salah satunya fasilitas transit yang berada di Rawa Buaya. Fasilitas transit Rawa Buaya dirancang dengan menggunakan teknik pengumulan data kualitatif dan cross-programming dalam perencanaan perancangan. Metode yang digunakan menghasilkan tiga program utama yang menekankan pada fungsi pelayanan, hiburan, dan komersil, yang membentuk interaksi sosial, ruang berkumpul, dan ruang untuk berinteraksi antar komunitas terminal bus Rawa Buaya.
\end{abstract}

Kata kunci: Jakarta; komunitas moda transportasi umum; sosial; third place; transit

\begin{abstract}
Jakarta is the second most populous city in the world with a population density of 10 million people in 2017. Density causes rapid development in the Jakarta area without any planning. The development that occurs makes the boundaries between office zoning located in the downtown area and residential zones located on the edge of the city. The zones formed have resulted in increased mobility that can be seen from vehicle ownership, transportation modes, and traffic congestion in Jakarta. Charles Montgomery in the book Happy City said that high congestion causes a decline in health that occurs due to stress for the community of public transportation modes. One way to reduce stress is to socialize according to Adhiatma and Christianto (2019). Third Place or social space becomes a solution for socializing for the public transportation community. The Third Place concept can be felt more by the public transportation community, where they can feel the difference between the housing zone and the office zone. The transit or transit place that is formed will be a social space that is used without differentiating social status. One of them is the transit facility located in Rawa Buaya. The Rawa Buaya transit facility is designed using qualitative data collection techniques and cross programming in design planning. The method used produces three main programs that emphasize service, entertainment and commercial functions, which shape social interaction, gathering space, and space for interaction between Rawa Buaya bus terminal communities.
\end{abstract}

Keywords: community modes of public transportation; Jakarta; social; third place; transit 


\section{PENDAHULUAN}

Indonesia memiliki beberapa kota besar yang berkembang menjadi kota metropolitan. Kota metropolitan terbentuk melalui bersatunya beberapa kota atau daerah administratif yang berdekatan menjadi kawasan perkotaan yang besar atau yang dikenal sebagai konurbasi antara kota inti dengan kota sekitarnya. Salah satu kota metropolitan di Indonesia adalah DKI Jakarta. DKI Jakarta merupakan kota administratif dan ibu kota negara Indonesia.

DKI Jakarta memiliki luas sekitar $661,52 \mathrm{~km}^{2}$ (laut :6.977,5 km²), dengan jumlah penduduk 10.177.924 jiwa tahun 2017 berdasarkan Wikipedia. Jakarta merupakan kota yang memiliki fungsi sebagai pusat bisnis, pusat politik, dan pusat kebudayaan di Indonesia. Hal ini membuat perkembangan kota Jakarta menjadi sangat cepat, yang mengakibatkan perpindahan penduduk dari desa ke kota (urbanisasi) meningkat.

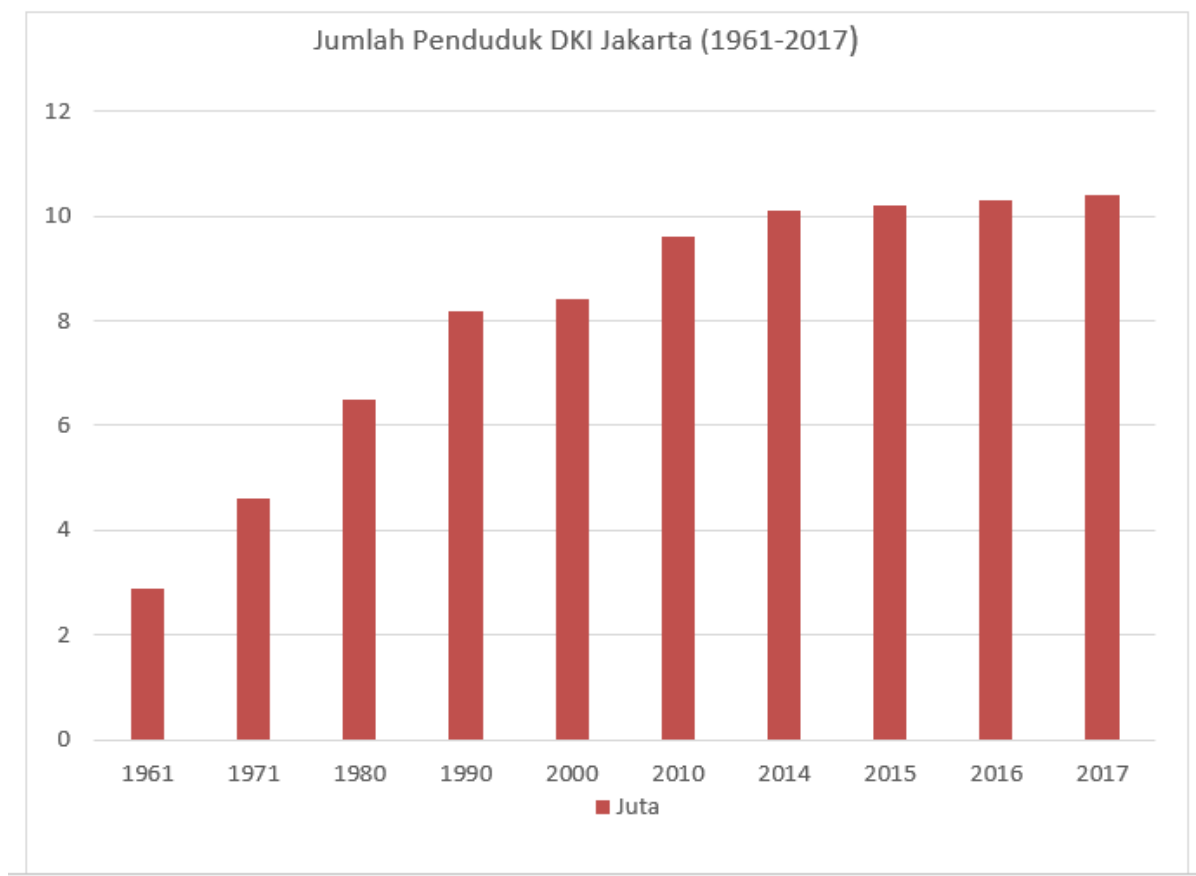

Grafis 1. Data Statik Jumlah Penduduk di DKI Jakarta

Sumber : Badan Pusat Statistik Provinsi DKI Jakarta, 2017

Berdasarkan data Badan Pusat Statisik, jumlah penduduk DKI Jakarta meningkat setiap tahunnya. Peningkatan penduduk mencapai 10,1 juta jiwa pada tahun 2017. Hal ini, menunjukkan bahwa kota Jakarta merupakan salah satu wilayah terpadat di Indonesia. Peningkatan penduduk terjadi dari tahun 1961 sampai 2017 yang tersebar di Jakarta. Dari tabel 1. Data Kepadatan penduduk di DKI Jakarta di bawah ini, terlihat bahwa Jakarta Barat memiliki luas wilayah ke empat, dengan kepadatan penduduk mencapai 18 ribu jiwa/ $\mathrm{km}^{2}$ dan jumlah penduduk terbanyak ke dua yang mencapai 2,43 juta jiwa.

Tabel 1. Data Kepadatan penduduk di DKI Jakarta

\begin{tabular}{|c|l|c|c|c|}
\hline TAHUN & $\begin{array}{c}\text { KABUPATEN ATAU KOTA } \\
\text { ADMINISTRASI }\end{array}$ & $\begin{array}{c}\text { LUAS } \\
\text { AREA }\end{array}$ & $\begin{array}{c}\text { JUMLAH } \\
\text { PENDUDUK }\end{array}$ & $\begin{array}{c}\text { KEPADATAN } \\
\text { PENDUDUK }\end{array}$ \\
\hline 2014 & Kepulauan Seribu & 8,70 & 23011 & 2644943,00 \\
\hline 2014 & Jakarta Selatan & 141,27 & 2164070 & 15318,68 \\
\hline 2014 & Jakarta Timur & 188,03 & 2817994 & 14967,83 \\
\hline 2014 & Jakarta Pusat & 48,13 & 910381 & 18915,04 \\
\hline 2014 & Jakarta Barat & 129,54 & 2430410 & 18761,85 \\
\hline 2014 & Jakarta Utara & 146,66 & 1729444 & 11792,00 \\
\hline
\end{tabular}

Sumber : Open Data, 2014 
Kepadatan penduduk di Jakarta berpusat disekitar jantung kota dan menjalar hingga wilayah di pinggir kota, salah satunya adalah kecamatan Cengkareng. Kecamatan Cengkareng merupakan kecamatan dengan jumlah penduduk terbanyak di DKI Jakarta yang dapat dilihat dari Grafis.2. 20 Kecamatan dengan Penduduk Terbanyak di DKI Jakarta 2014. Kecamatan Cengkareng memiliki luas 3.009 ha dengan jumlah penduduk 494.700 ribu jiwa. Padatnya penduduk membuat kota Jakarta berkembang dengan cepat, sehingga menimbulkan pembangunan gedung meningkat tanpa adanya perencanaan.

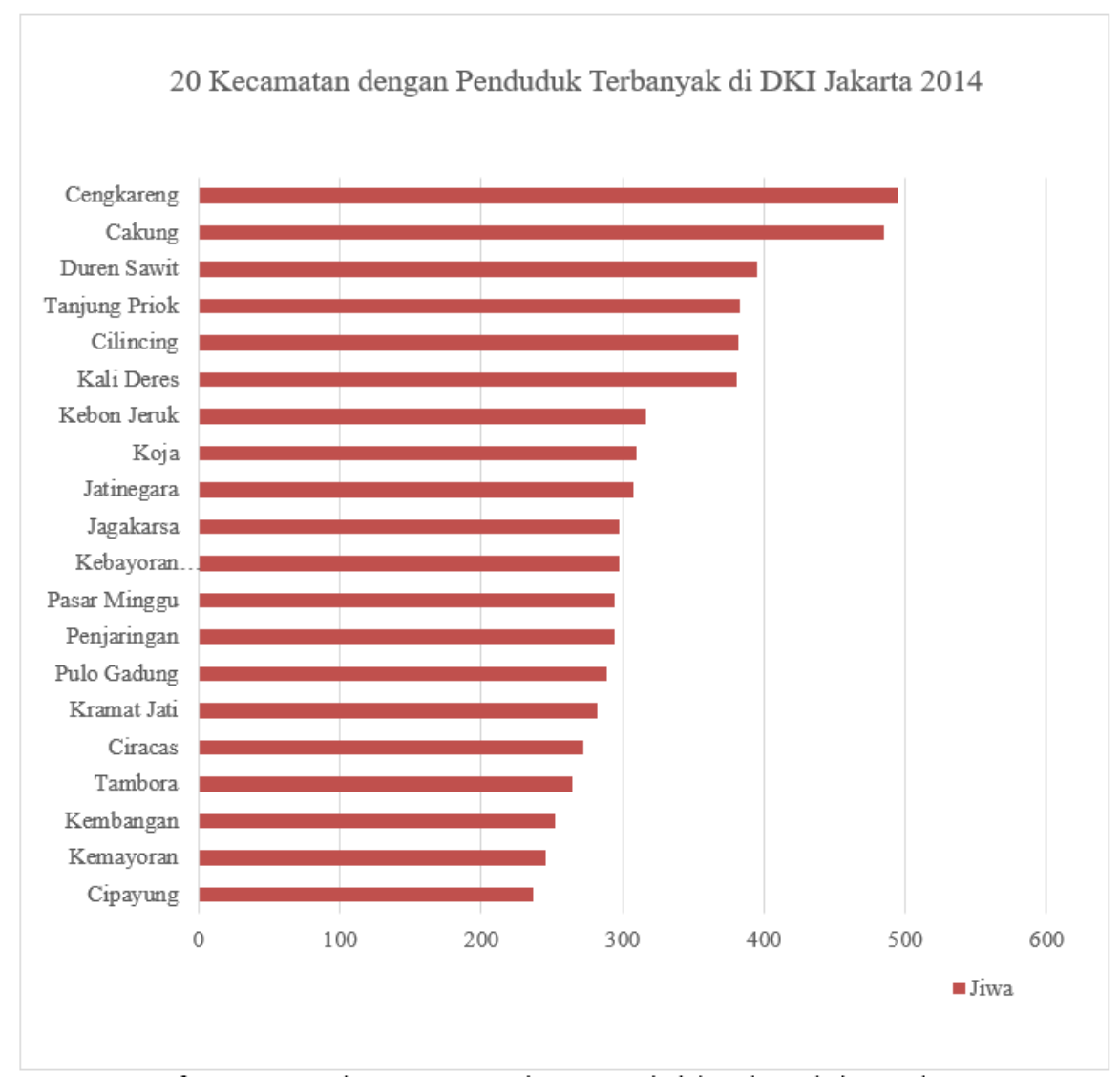

Grafis 2. Data Statik 20 Kecamatan dengan Penduduk Terbanyak di DKI Jakarta Sumber : Badan Pusat Statistik Provinsi DKI Jakarta, 2015

Terlihat pada Gambar 1. Peta Zonasi di DKI Jakarta, bahwa perkembangan kota Jakarta yang sangat cepat menimbulkan batas antara zona hunian dengan zona kerja. Zona kerja berada di pusat kota Jakarta dan zona hunian berada di tepi kota Jakarta salah satunya adalah kecamatan Cengkareng, Hal ini mendorong terjadinya pergerakan atau mobilitas penduduk meningkat pada kawasan hunian dengan kawasan kantor atau industri. Mobilitas merupakan sebuah pergerakan atau perpindahan dari satu tempat ke tempat lain. Besarnya jarak tempuh menjadi fokus dan indikator dari pergerakan mobilitas. 


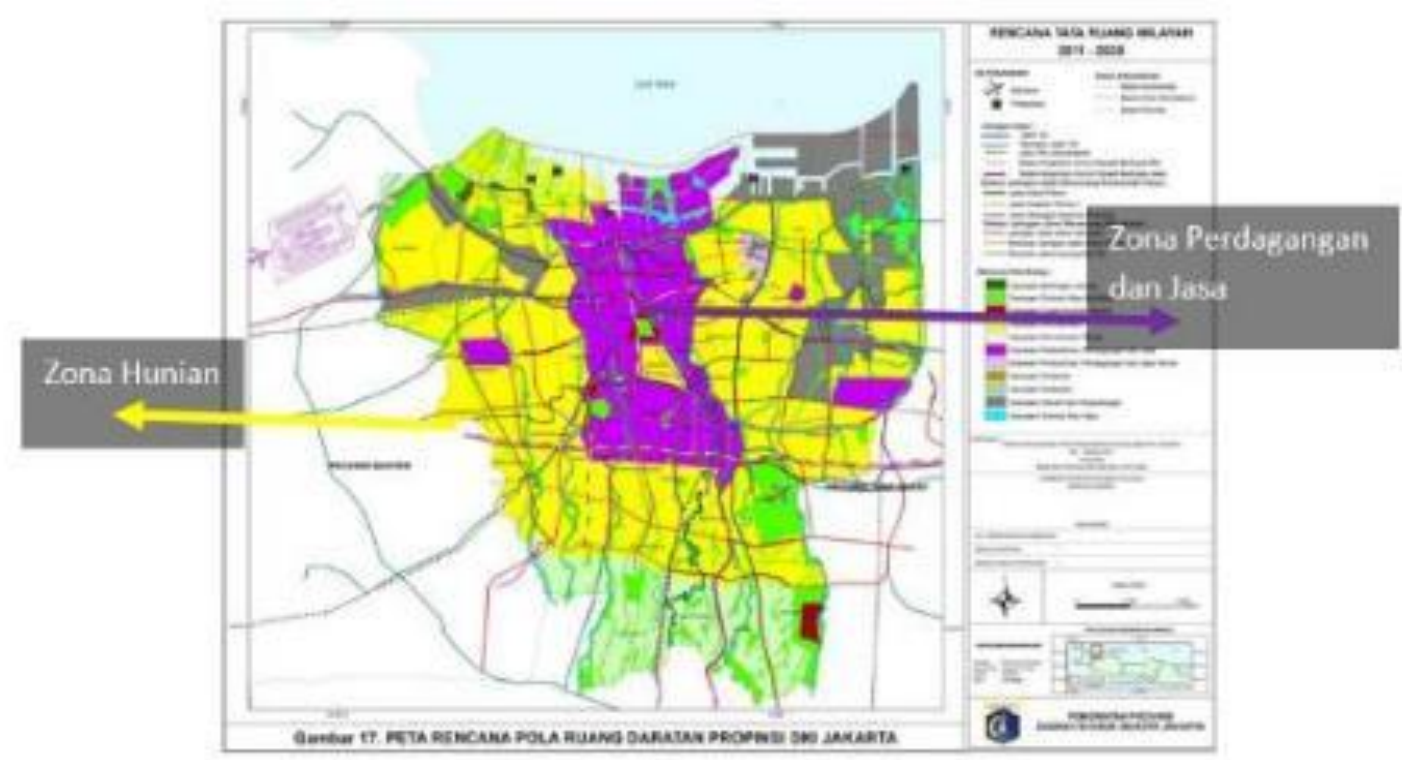

Gambar 3. Peta Zonasi di DKI Jakarta

Sumber: flickr.com, 2011

Mobilitas, terutama dengan kendaraan bermotor memerlukan lahan yang semakin besar, baik di dalam kota maupun di pedesaan. Kota Jakarta memiliki jumlah kendaraan yang tinggi, sehingga sebagian besar dari ruang kota digunakan untuk jalan raya. Kepemilikan kendaraan pribadi yang meningkat setiap tahunnya, membuat volume kendaraan di Jakarta semakin menumpuk atau padat dan peningkatan polusi udara. Tingginya volume kepadatan kendaraan pribadi memicu kemacetan di Jakarta, Jauhnya sebuah tempat tidak lagi diukur dengan jarak $(\mathrm{km})$ melainkan waktu yang dihabiskan dalam perjalanan.

Table 2. Data kepemilikan kendaraan pribadi di DKI Jakarta

\begin{tabular}{c|c|c|c|c}
\hline TAHUN & $\begin{array}{c}\text { JUMLAH } \\
\text { MOBIL }\end{array}$ & $\begin{array}{c}\text { JUMLAH } \\
\text { MOTOR }\end{array}$ & $\begin{array}{c}\text { PERTAMBAHAN MOBIL / } \\
\text { TAHUN }\end{array}$ & $\begin{array}{c}\text { PERTAMBAHAN } \\
\text { MOTOR/ TAHUN }\end{array}$ \\
\hline 2008 & 2295644 & 3968749 & 244516 & 560442 \\
\hline 2009 & 2355354 & 4333559 & 169108 & 476008 \\
\hline 2010 & 2505133 & 4835650 & 160855 & 478345 \\
\hline 2011 & 2665988 & 5313995 & 149779 & 502091 \\
\hline 2012 & 2801918 & 5650925 & 135930 & 336930 \\
\hline 2013 & 3046434 & 6211367 & 77264 & 389127 \\
\hline 2014 & 3215542 & 6687375 & 59710 & 364810 \\
\hline
\end{tabular}

Sumber : Data Jakarta, 2018

Penelitian Uber dengan Boston Consulting Group, mengatakan warga Jakarta dapat menghabiskan 22 hari dalam setahun di jalan. Jumlah tersebut dihitung dari pengendara di Jakarta yang menghabiskan waktu 68 menit di jalan dan 21 menit mencari tempat parkir. Hal ini juga dipengaruhi jarak antar zona hunian dengan zona perkantoran. Jarak dan waktu tempuh yang panjang dapat mempengaruhi kesehatan, baik mereka yang menggunakan kendaraan pribadi atau transportasi. Charles Montgomery dalam buku Happy City juga mengatakan tentang pengemudi mengalami stress lebih berat saat peak rush hour dibandingkan dengan pilot yang berada di wilayah lain. University of Texas Dallas dalam Jurnal Urban Geography melalui data statistik tentang urban-rular happiness gradient, membuktikan turunnya subjective wellbeing. 


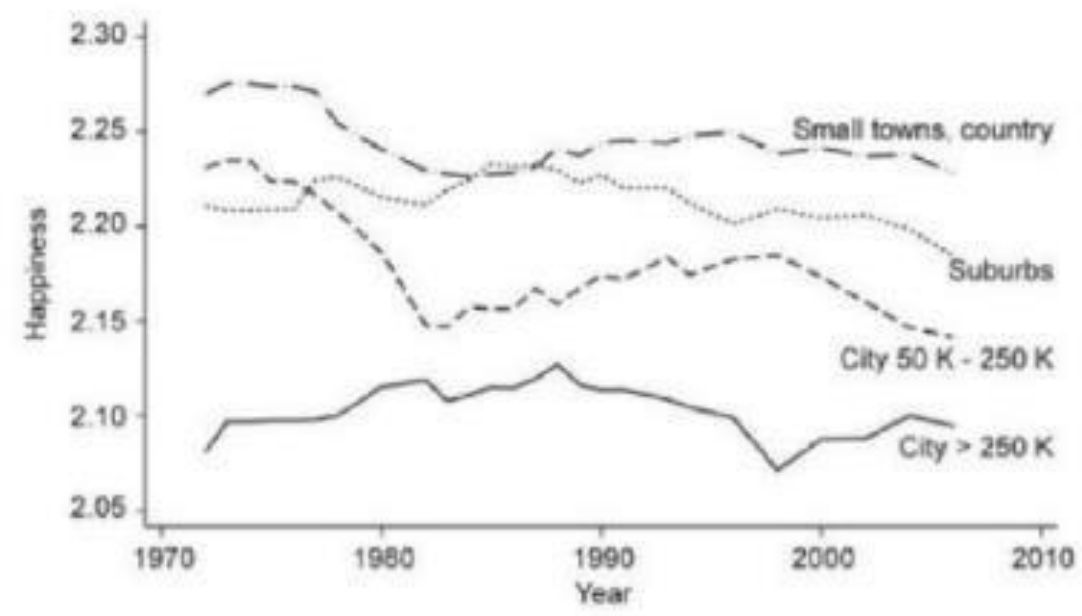

Gambar 4. Survei G.S.S (General Social Survey) tahun 1972-2014 Sumber: Tom W. Jaesok \& Beniamin, 2015

Menurut keterangan Professor Erik Hansenn pengguna mobil dan transportasi umum menderita stress dan memiliki kualitas tidur yang buruk dibandingkan para komuter aktif. Professor Hansenn juga mengatakan tentang kesehatan yang buruk dipengaruhi oleh penggunaan transportasi publik yang meningkat seiring dengan panjangnya jarak perjalanan.

Kepadatan Penduduk, Mobilitas yang tinggi, dan Batasan Zona Bangunan mendorong warga Jakarta terbiasa bersikap individualis dan rentan terhadap stress. Hal ini membuat kota Jakarta memerlukan Third Place sebagai sarana untuk melepas stress dan mengembalikan komunitas serta kebudayaan yang telah hilang. Sarana yang tepat dalam mendesain Third Place pada area transportasi umum. Transportasi umum merupakan salah satu tempat yang paling tepat untuk menghindari masyarakat dari penyakit dan stress (Montgomery, 2013).

\section{KAJIAN LITERATUR}

\section{Open Architecture}

"Open Architecture-in the sense of welcoming alterity and accommodating discordant realities-takes place on the level of designed metaphor, while the assumption of the architect's authorial status remains intact". (Akcan, 2018)

Esra Akcan mengemukakan Open Architecture yang berhubungan dengan Open City dan Open Society. Open city berfungsi untuk membuat kota lebih baik dengan menggunakan open system (sistem yang terbuka secara sosial) dengan menggabungkan unsur-unsur yang ada di dalam kota. Open System mendukung dan merangkul karakter kota menjadi adaptif dan eksperimental. Open city dan open society berbicara tentang lingkungan campuran yang melibatkan kehidupan kota secara informal, dimana masyarakat lokal dapat berinteraksi dengan kehidupan kota dalam membuat kerumunan orang di jalan atau alun-alun untuk berkumpul tanpa memperhatikan kualitas lingkungan.Pada kota modern open architecture tidak digunakan akibat batas dalam kota yang mendominasi, seperti pembatasan fungsi antar zona pekerja, pedagang, keluarga, dan tempat publik. Batas membuat bangunan dengan lingkungannya tidak dapat berinteraksi yang mengakibatkan perbedaan antar kelompok atau menjadi individualis secara sosial (Akcan, 2018). Hal ini membuat kota modern memerlukan Open Architecture yang berfungsi dalam mengembangkan mekanisme yang fleksibel pada kota modern, serta menyelesaikan perbedaan yang tak terhindarkan ke dalam ruang fisik seperti Third Place.

\section{Third Place}

Ray Oldenburg dalam karyanya The Greet Good place mengemukakan tempat ketiga merupakan lingkungan sosial yang terpisah dari dua lingkungan antara rumah (first place), dan 
tempat kerja (second place). Tempat ketiga adalah "jangkar" kehidupan komunitas dan memfasilitasi dan mendorong interaksi yang lebih luas dan lebih kreatif (Myers, 2012).

Kemunculan Third Place disebabkan dari faktor revolusi Industri, dimana tempat bekerja dan tempat tinggal berada di tempat yang berbeda (Oldenburg, 1999). Pada kondisi modernisasi dan pembangunan mengubah kota kecil menjadi kota metropolitan, Hal ini menyebabkan surbubanisasi (pembangunan pemukiman dan kawasan industry baru di pinggir wilayah perkotaan). Letak pemukiman yang terpisah jauh dari pusat kota memaksa pegerakan mobilitas. Lingkungan yang dahulu memiliki tempat untuk bersosialisasi di tengah pemukiman seperti kafe atau bar menghilang keberadaanya. Hal ini membuat individu didalamnya hanya memiliki kesempatan kecil untuk merasa saling terkait dalam sebuah hubungan sosial dengan sekitarnya.

Keterbatasan untuk mendapatkan kehidupan sosial membuat perasaan kesepian dan bosan mudah dirasakan. Pada akhirnya manusia menjadi individualis atau menutup dirinya dengan warga kota. Oldenburg mengatakan bahwa masyarakat yang tinggal di pinggir kota, memilih untuk bekerja sebagai cara untuk mendapatkan pengganti kehidupan sosialnya. Ibu rumah tangga yang bekerja di dalam rumah, memilih untuk memiliki kendaraan agar dapat keluar dan dapat bersosialisasi. Hal ini membuat peningkatan kepemilikan kendaraan meningkat.

Kota modern yang memiliki pergerakan mobilitas yang tinggi, membuat peningkatan pada komuter, polusi, dan kriminalitas (Montgomery, 2013). Charles Montgomery mengatakan semakin lama pengendara mobil membuat kurangnya kesenangan masyarakat. la menyarankan perancangan transportasi diulang untuk menimalisir kendaraan pribadi, serta menghindari masyarakat dari penyakit atau stress dalam berkendara. Hal ini dapat meningkatkan kehidupan sosial, penggunaan sepeda, dan berkurangnya kriminalitas dalam transportasi umum.

Pengalaman didalam transportasi umum menjadi konsep third place, dimana transportasi umum menjadi bagian dari elemen ruang publik pada kota (Dolley \& Bosman, 2019). Buku ini menyatakan bagaimana Oldenburg, memperkenalkan konsep third place tahun 1980, yang kemudian mengalami banyak perubahan yang terjadi di dalam kota dari perubahan praktik kerja dan pengembangan teknologi. Kota yang terus berkembang menjadi wilayah dengan batasan antara tempat kerja dan rumah di pinggir.

Kota yang jauh yang telah dikatakan Oldenburg, memiliki jarak antara tempat kerja dan aktifitas lainnya menjadi tidak terlihat dengan banyaknya orang yang bekerja dan beraktifitas jauh dari tempat kerja, dan termaksud saat berada di dalam transportasi umum. Tujuan antara rumah, tempat kerja dan third place menjadi tidak terlihat. Seiring dalam perjalanan waktu, komunitas pada transportasi umum lebih dapat merasakan keberadaaan third place, karena komunitas transportasi umum lebih menikmati perjalanannya antara rumah dan tempat kerja dibandingkan menjadi pengalaman buruk saat berada di transportasi umum setiap harinya (Dolley \& Bosman, 2019).

\section{Karakteristik Third Place}

Third Place memiliki beberapa karakteristik menurut Oldenburg yakni:

a. Neutral Ground

Setiap individu dapat datang dan pergi sesuai keinginannya, mereka tidak terikat pada third place secara finansial, politik, hokum, atau lainnya.

b. Status (leveler)

Third place tidak mementingkan status ekonomi atau sosial seseorang dalam suatu masyarakat. Tidak ada syarat atau hirearki sosial untuk berpartisipasi di dalam Third Place.

c. Percakapan adalah aktivitas utama Percakapan yang menyenangkan adalah focus utama dari kegiatan Third Place.

d. Accessibility dan Akomodasi

Third Place harus terbuka, mudah diakses, dan akomodatif (memenuhi kebutuhan).

e. Pengunjung Tetap

Third Place memiliki pengunjung tetap, hal ini memberikan atmosfir dalam ruang dan membantu interaksi sosial. 
f. Terlihat sederhana (low profile)

Bentuk Third Place terlihat sederhana, untuk menguatkan kesan leveling pelanggan yang datang dengan penampilan apa adanya.

g. Mood yang menyenangkan

Percakapan di dalam Third Place bersifat menyenangkan, canda dan tawa lebih umum terdengar menjadi daya tarik Third Place di lingkungan sosial.

h. A home away from home

Pengunjung Third Place memiliki rasa hangat tanpa adanya kepemilikan pada bangunan.

\section{Stress}

"Stress is a substantial imbalance between demand (physical and/or psychological) and response capability, under conditions where failure to meet that demand has importance consequences". (Waitz, Strømme, \& Railo, 1983)

Istilah stress seakan adalah bagian yang tidak dapat terpisahkan dari kehidupan di kota modern (Oldenburg, 1999). Stress merupakan salah satu artibut kehidupan modern (Kupriyanov \& Zhdanov, 2014). Stress muncul secara tiba-tiba dengan penyebab yang berbeda pada setiap individu. Faktor penyebab stress dapat berasal dari dalam diri individu dan dari luar diri individu. Stress dapat terjadi di lingkungan sekitar dan memiliki dampak terhadap kesehatan individu. Salah satu cara untuk mengurangi stress adalah berbagi cerita atau bersosialisasi dan melakukan aktivitas yang disukai atau menggembirakan (Adhiatma \& Christianto, 2019).

\section{Pengertian Transportasi Hub}

$\mathrm{KBBI}$ transit adalah tempat singgah kemampuan untuk menciptakan yang bersifat daya cipta. Berdasarkan Wikipedia, Transportasi hub adalah tempat dimana penumpang dan kargo dipertukarkan antara kendaraan dan antara moda transportas. Bangunan Transportasi Hub merupakan sebuah bangunan yang melayani perpindahan pergerakan manusia dan barang bawaan. Berbagai macam moda transportasi berlokasi saling berdekatan dengan moda transportasi yang lainnya. Fungsi utama bangunan yang dapat menampung seluruh kegiatan operasional dan pendukung secara efisien serta terpadu antara lain:

- Fungsi transportasi hub, dapat menampung seluruh kegiatan utama operasional transportasi seperti area drop off dan area menunggu yang terkontrol serta,

- Fasilitas pendukung dari fungsi transportasi hub, seperti:

- $\quad$ Area Komersil (bersifat sewa) dan pendukungnya

- $\quad$ Area Perkantoran dan pendukungnya

- $\quad$ Area Penghubung antara transport hub dengan kawasan sekitar.

- Area drop off yang terkontrol untuk transportasi public seperti bus TransJakarta dan Taksi yang diharapkan dapat berbagi dengan area drop off terkontrol untuk pengguna kendaraan pribadi

- Area drop off (dedicated space) yang terkontrol untuk transportasi online (ride sharing) seperti ojek online dan taksi online.

\section{Pengertian Fasilitas}

Fasilitas adalah sarana untuk melancarkan pelaksanaan fungsi atau kemudahan berdasarkan kamus KBBI. Fasilitas juga dapat dikatakan sebagai segala sesuatu yang dapat memudahkan dan melancarkan pelaksanaan suatu usaha dan merupakan sarana dan prasarana yang dibutuhkan dalam melakukan atau mempelancar suatu kegiatan. Pada arsitektur pengertian fasilitas dapat diartikan sebagai wadah, bentuk tempat, ruang, dan bangunan yang didapat digunakan secara umum. Sehingga, fasilitas dapat menampung kegiatan atau interaksi pengguna. 


\section{Pengertian Fasilitas Transportasi Hub}

Berdasarkan pengertian fasilitas dan Transportasi Hub dapat dikatakan bahwa fasilitas merupakan sarana penunjang kebutuhan suatu fungsi bangunan, dan Transportasi Hub yang merupakan tempat singgah atau bangunan yang melayani pergerakan kebutuhan manusia. Fasilitas Transportasi Hub memiliki fungsi penunjang dalam melayani kebutuhan pergerakan kebutuhuan dalam moda transportasi umum.

\section{METODE}

Metode yang dilakukan menggunakan beberapa pendekatan dalam mendapatkan informasi yang diperlukan untuk melakukan perancangan, yaitu:

a. Metode Kualitatif dengan menekankan aspek pemahaman secara mendalam terhadap suatu permasalahan. Metode ini menggunakan riset yang bersifat deduktif serta menggunakan analisis yang mengacu pada proses dan makna.

b. Metode Perancangan menggunankan metode Cross programming yang berasal dari Bernard Tschumi. Metode ini berfungsi untuk menentukan dan membatasi aktivitas pada bangunan dengan aspek program yang kompleks dan saling bertentangan dari realitas kontemporer yang dipadukan didalam fungsi bangunan.

Sesuai dengan metode yang digunakan mendapatkan data yang dianalisa dan menghasilkan usulan program ruang yang akan diterapkan dalam perancangan.

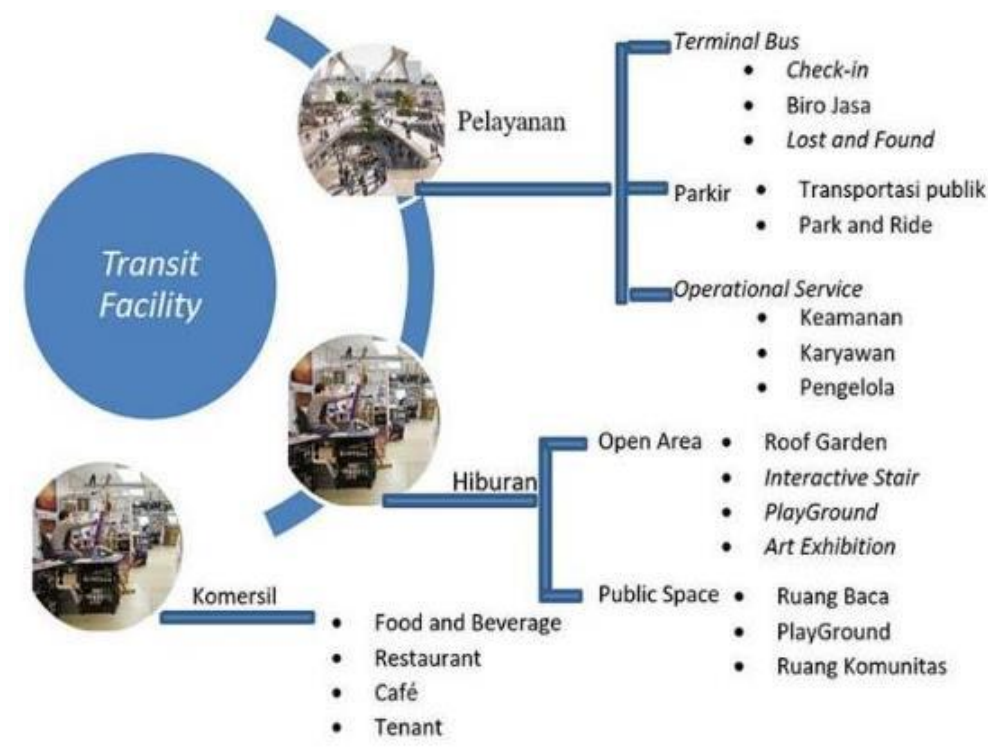

Gambar 5. Skema Aktivitas Program Transit Facility Sumber: Penulis, 2019

\section{DISKUSI DAN HASIL}

\section{Analisa Kawasan}

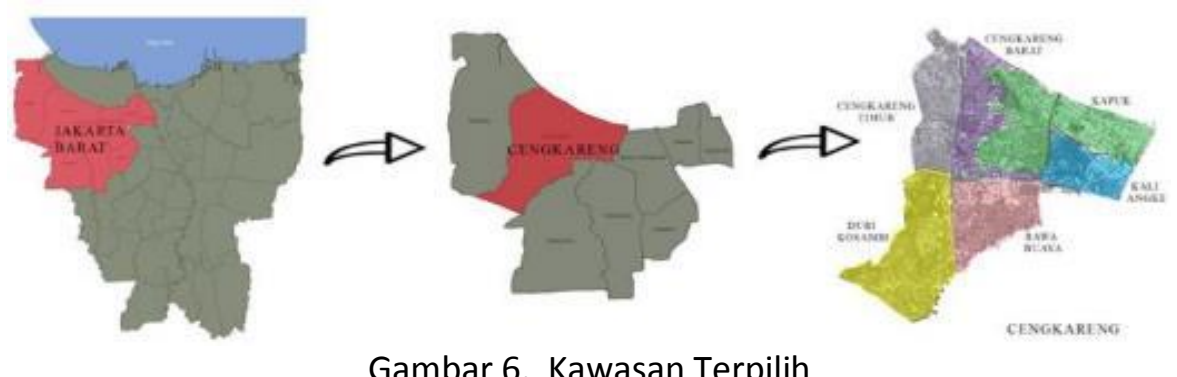

Gambar 6. Kawasan Terpilih

Sumber: Penulis, 2019 
Kawasan dipilih berdasarkan karakteristik third place sebagai tempat untuk bersosialisasi yang tidak membedakan stastus sosial dan isu yang terkait pada latar belakang serta kajian teoritikal mengenai kepadatan penduduk yang dapat menyebabkan penigkatan pergerakan mobilitas dan menimbulkan stress bagi masyarakat terutrama pengguna transportasi umum. Salah satu kecamatan yang ada di DKI Jakarta adalah kecamatan Cengkareng .

Tapak berada di dalam rancangan bangunan pemerintah yang sedang melakukan DED dalam perencanaan Terminal Bus AKAP Rawa Buaya, Kelurahan Duri Kosambi, Kecamatan Cengkareng. Terminal Bus AKAP Rawa Buaya memiliki sub zona S.7 yang merupakan zona pelayanan umum dan sosial. Data Tapak: KDB 40\%, KLB 1,6, KDH 30\%, KB 4, KTB 55\%, Luas tapak: $\pm 2.923 \mathrm{~m}^{2}$

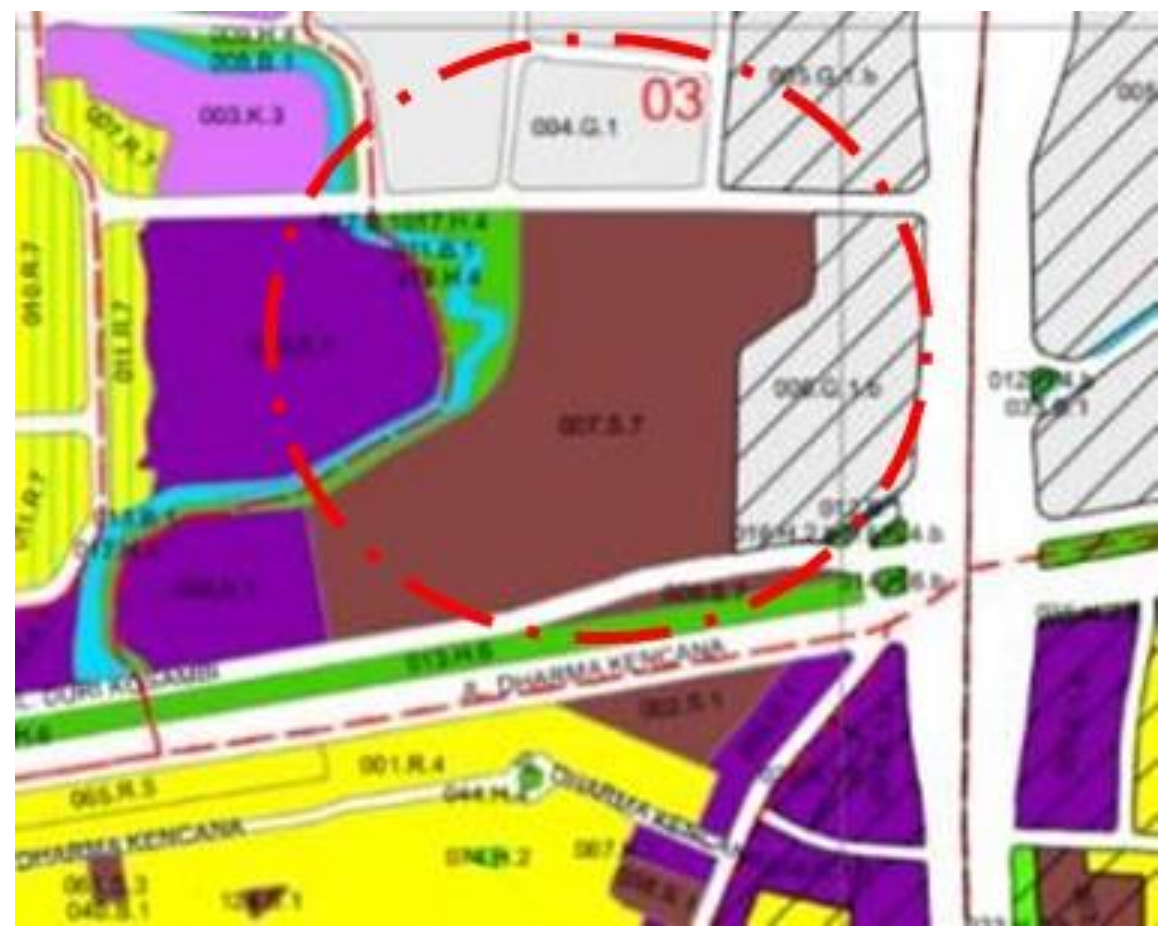

Gambar 7. Peta Zonasi Terminal Rawa Buaya

Sumber: Pemprov DKI Jakarta, 2019

Rencana pemerintah dalam perancangan pembangunan Terminal Bus AKAP Rawa Buaya dapat dilihat dari Gambar 5. Perspektif Terminal dan Gambar 6. Denah Perancangan Terminal Bus AKAP Rawa Buaya.

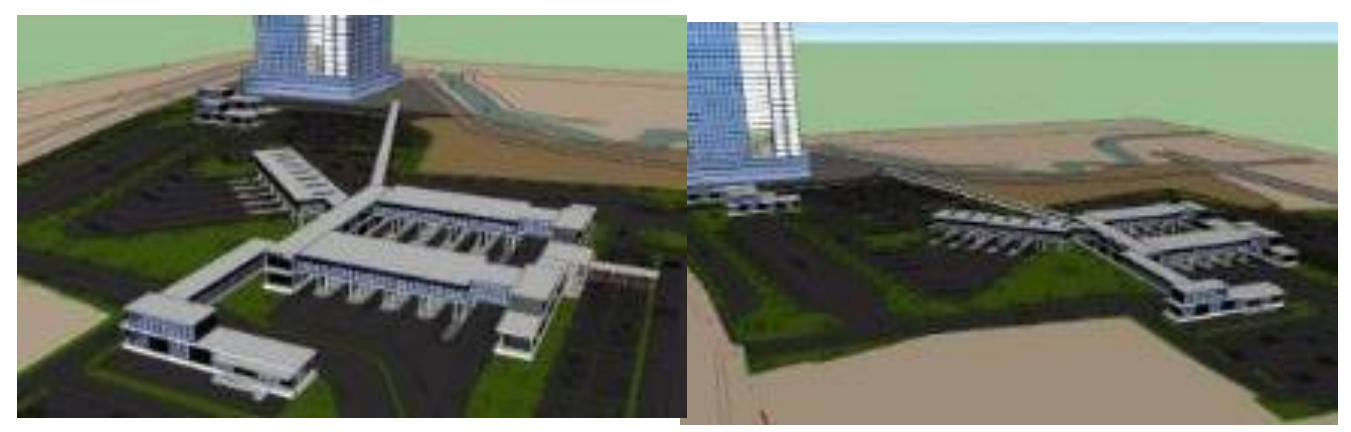

Gambar 8. Perspektif Terminal Rawa Buaya Sumber: Dinas Perhubungan DKI Jakarta, 2019 

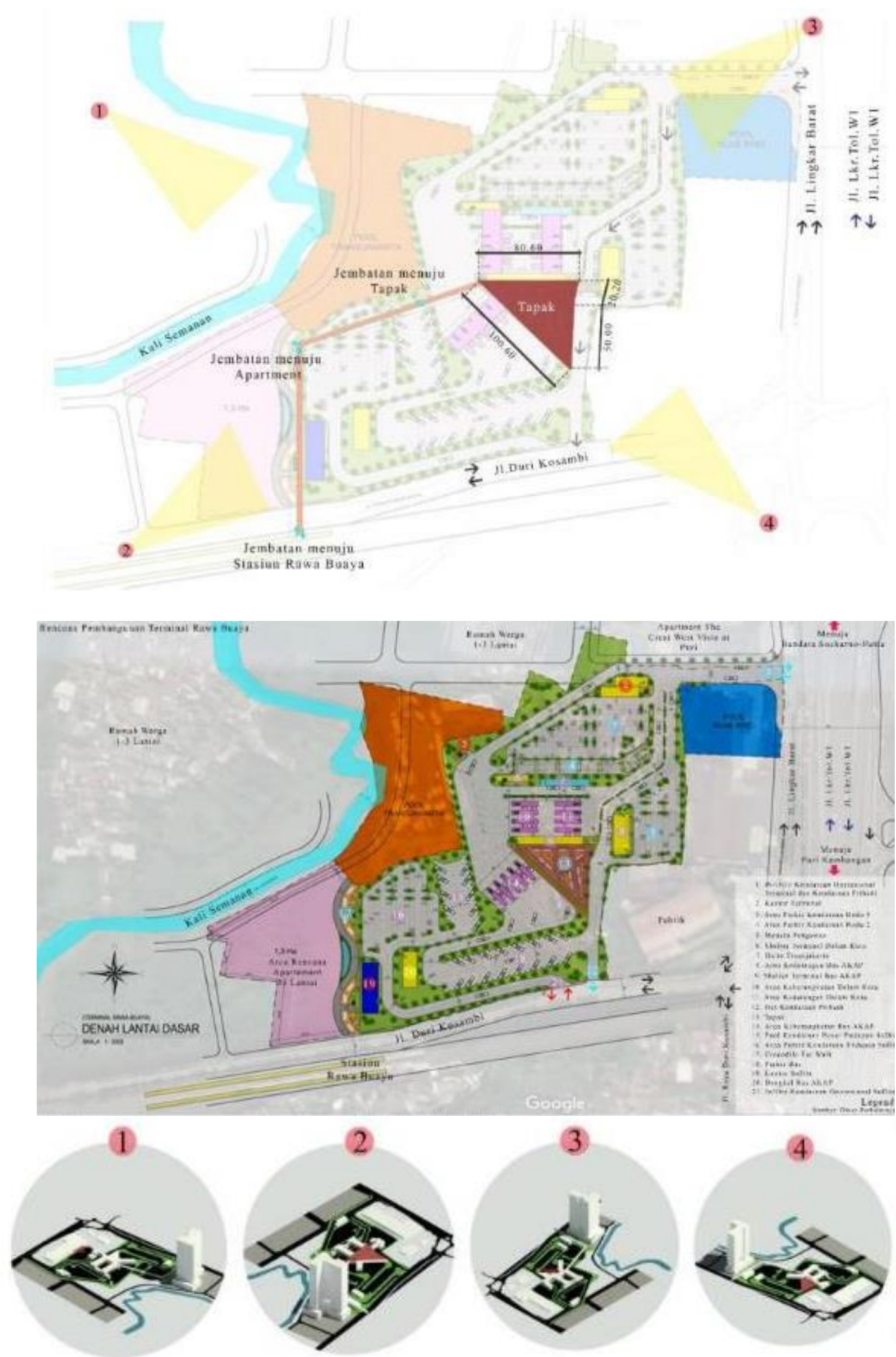

Gambar 9. Denah Perancangan Terminal Bus AKAP Rawa Buaya Sumber: Dinas Perhubungan DKI Jakarta, 2019 
Konsep pada bangunan, terinspirasi dari karakteristik third place yang memfokuskan pada komunikasi dan bentuk yang sederhana. Tema bangunan menggunakan industrial sebagai bentuk keterbukaan. Massa bangunan dibagi menjadi tiga massa berdasarkan program utama sebagai pelayanan, hiburan, dan komersil. Massa pada fungsi komersil dan hiburan memiliki ketinggian yang sama namun berbeda dengan massa pada bangunan pelayanan. Hal ini, dikarenakan efisiensi sirkulasi pada fungsi pelayana dan pemisahan program dengan jelas. Bentuk kota pada bangunan disesuaikan dengan bangunan disekitar tapak yang juga memiliki bentuk kotak, atap memiliki kemiringan untuk kepentingan penanggulangan saat hujan. Bangunan ini, merupakan bangunan semi outdoor yang mengutamakan ruang luar, sebagai ruang sosial yang dapat digunakan semua pengunjung.

\section{KONSEP}

THIRD PLACE

TERMINAL BUS AKAP RAWA BUAYA

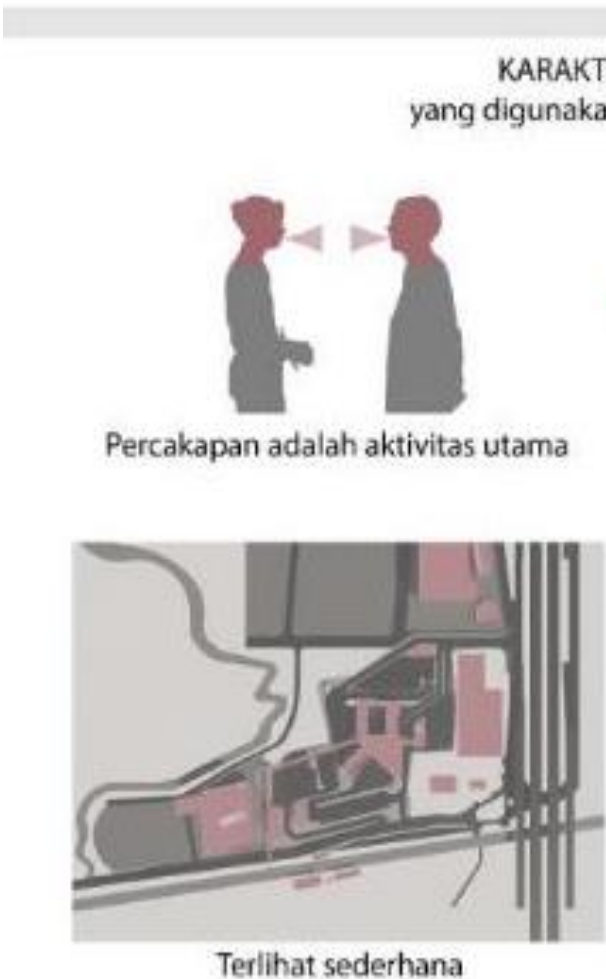

Terlihat sederhana

\section{TEMA}

Third Place harus terbuka

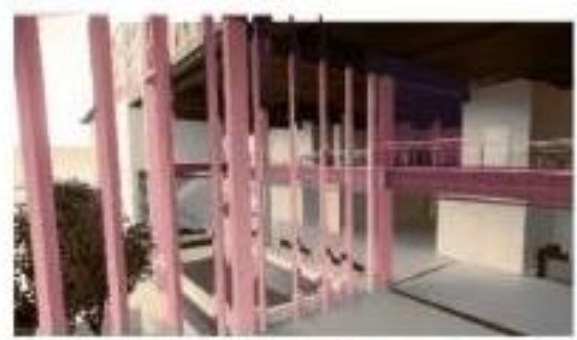

Menggunakan tema industrial dengan mengekspos material yang digunakan sebagai bentuk kesederhanaan dan keterbukaan bangunan

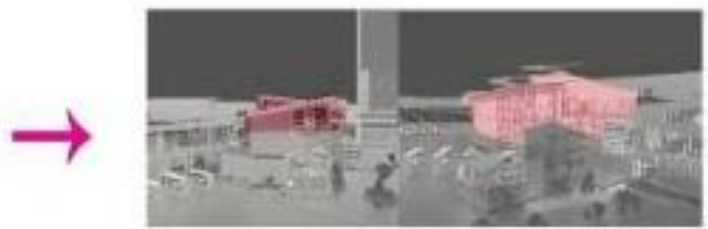

Bentuk atap bagian dari sebuah percakapan antar massa bangunan

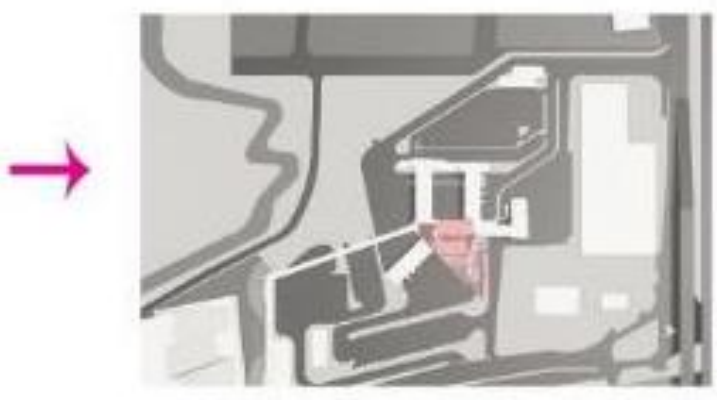

Bentuk Massa berbentuk kotak sebagai bentuk sederhana dan tanpa mengubah bentuk dan site pada bangunan disekitar tapak

Gambar 10. Konsep dan Tema Fasilitas Transit Rawa Buaya Sumber: Penulis, 2019 


\section{DESIGN SCHEME}

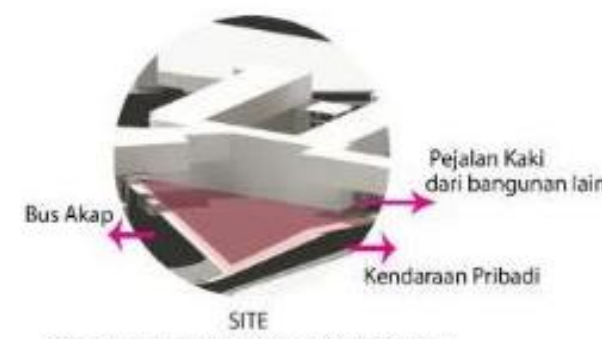

Tapak berada dekat dengan jalur sirkulasi kendaraan, baik kendaraan pribadi maupun bus. Tapak merupakan koneksi antar bangunan terminal bus Rawa Buaya, sehingga dapat dilalui oleh pejalan kaki

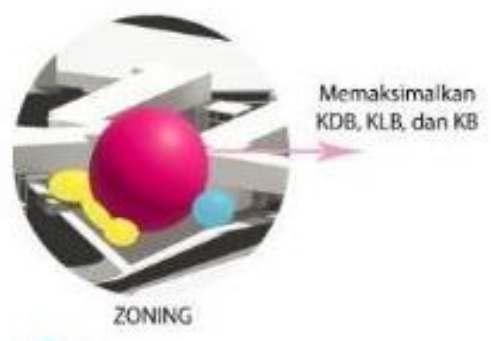

Entrance

Service dan Pelayanan

Komersil dan Hiburan

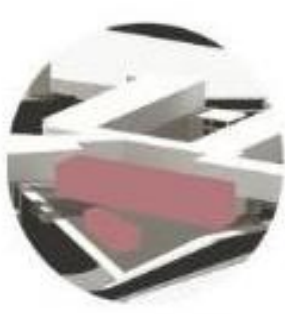

BENTUK DASAR

Bentuk mengikuti bangunan disekitar tapak yang berbentuk persegi dan persegi panjang Membentuk Grid $12 \times 10$ meter yang akan terbagi sesuai dengan kebutuhan
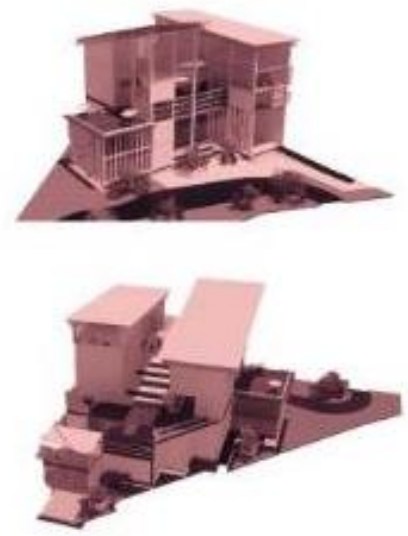

FINAL MASSING

Bentuk bangunan terinspirasi dari konsep Third Ploce dengan menyesuaikan karakteristik dari Thind Place

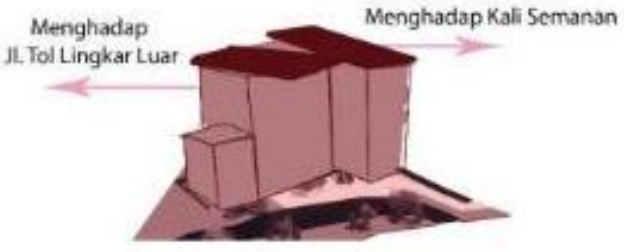

ORIENTASI MASSA

Atap memiliki kemiringan yang berfungsi sebagai petunjuk arah, yang menghadap ke arah Jalan raya dan Kali Semanan
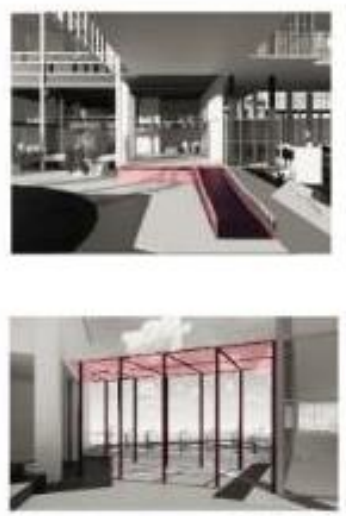

KONEKSI

Koneksi antar bangunan menggunakan ramp dan tangga pada lantai dasar, sedangkan pada lantai 3 terdapat Roof Garden yang dilengkapi dengan kanopi berfungsi sebagai koneksi antar bangunan dengan

Gambar 11. Design Scheme Fasilitas Transit Rawa Buaya Sumber: Penulis, 2019

Tapak berbentuk segitiga yang terletak di tengah rancangan keberangkatan bus AKAP dan bus AKDP, dengan sirkulasi kendaraan pribadi di dalam tapak hanya digunakan untuk drop off penumpang. Hal ini dikarenakan prinsip TOD pada rancangan pemerintah yang membuat parkir kendaraan pribadi berada di luar bangunan utama untuk memisahkan jalur pedestrian 
dengan kendaraan. Bentuk entrance bangunan disesuaikan dari simulasi sirkulasi berdasarkan rencana bangunan terminal bus AKAP dari Dinas perhubungan. Entrance menghadap timur dengan view menghadap ke jalan.

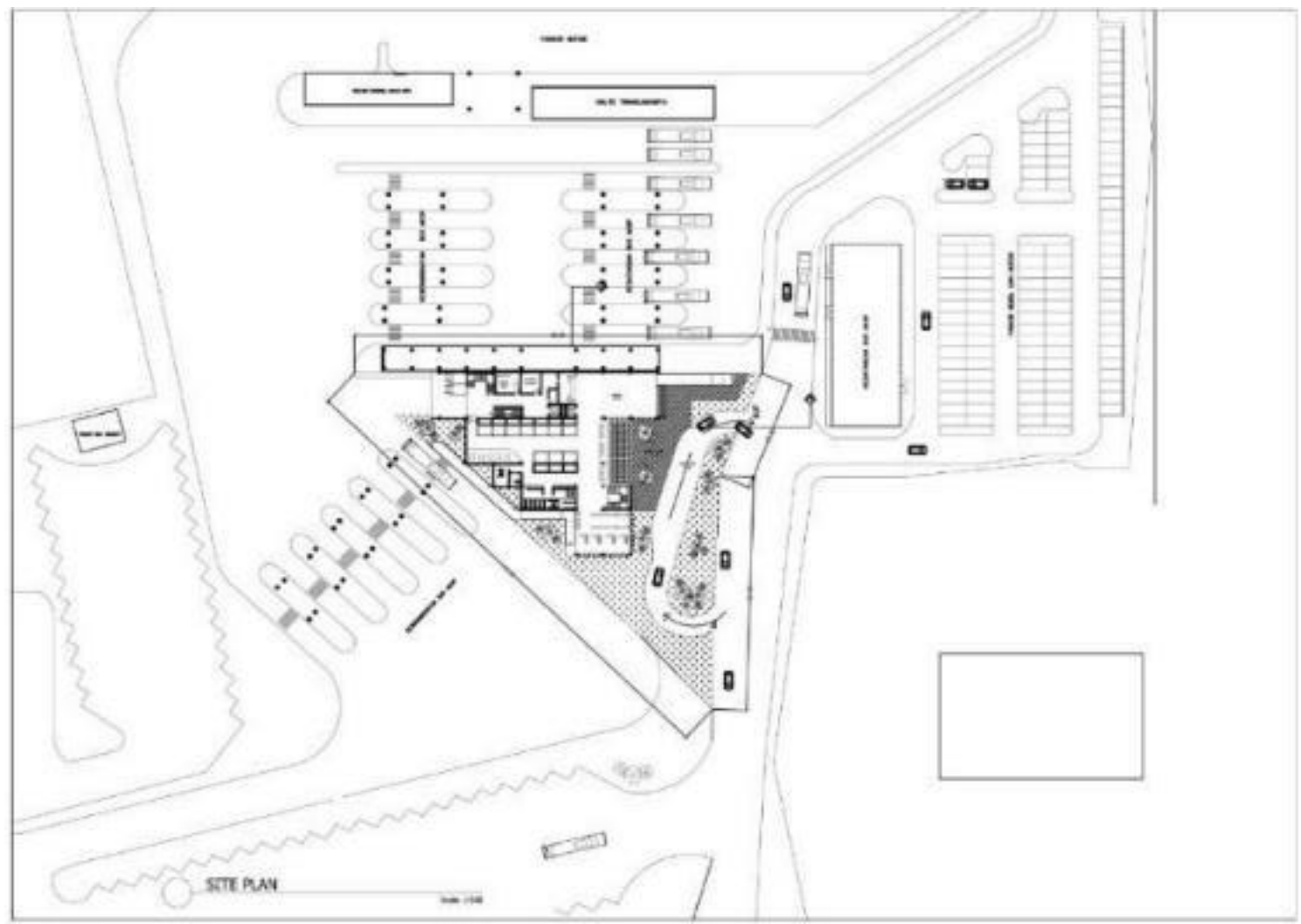

Gambar 12. Site Plan Fasilitas Transit Rawa Buaya Sumber: Penulis, 2019

Bangunan memiliki tiga tampak yang mengarah langsung pada jalan utama dan jalan bus yang dapat terlihat pada Gambar 10. Tampak Fasilitas Transit Rawa Buaya. Tampak bangunan mengikuti bentuk bangunan yang sudah ada dengan menggunakan material kaca dan beton. Pada lantai ke-3, terdapat rooftop yang berfungsi untuk menyatukan sekeliling bangunan dengan bangunan rencana pemerintah menggunakan penyamaan ketinggian lantai bangunan yang dapat dilihat pada Gambar 11.

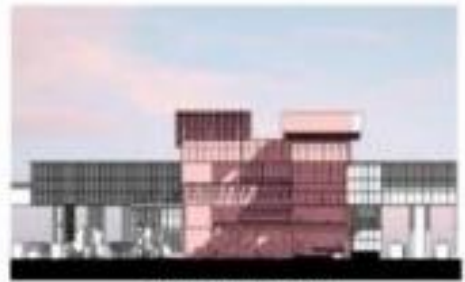

TAMPAK DEPAN

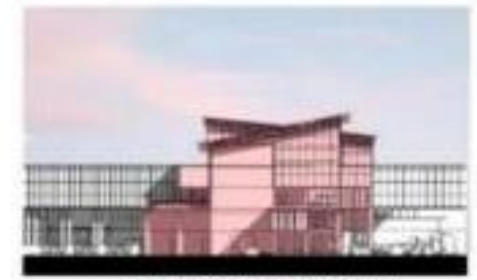

TAMPAK SAMPING KIRI

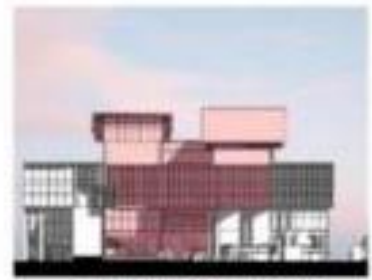

TAMPAK BELAKANG

Gambar 13. Tampak Fasilitas Transit Rawa Buaya

Sumber: Penulis, 2019 


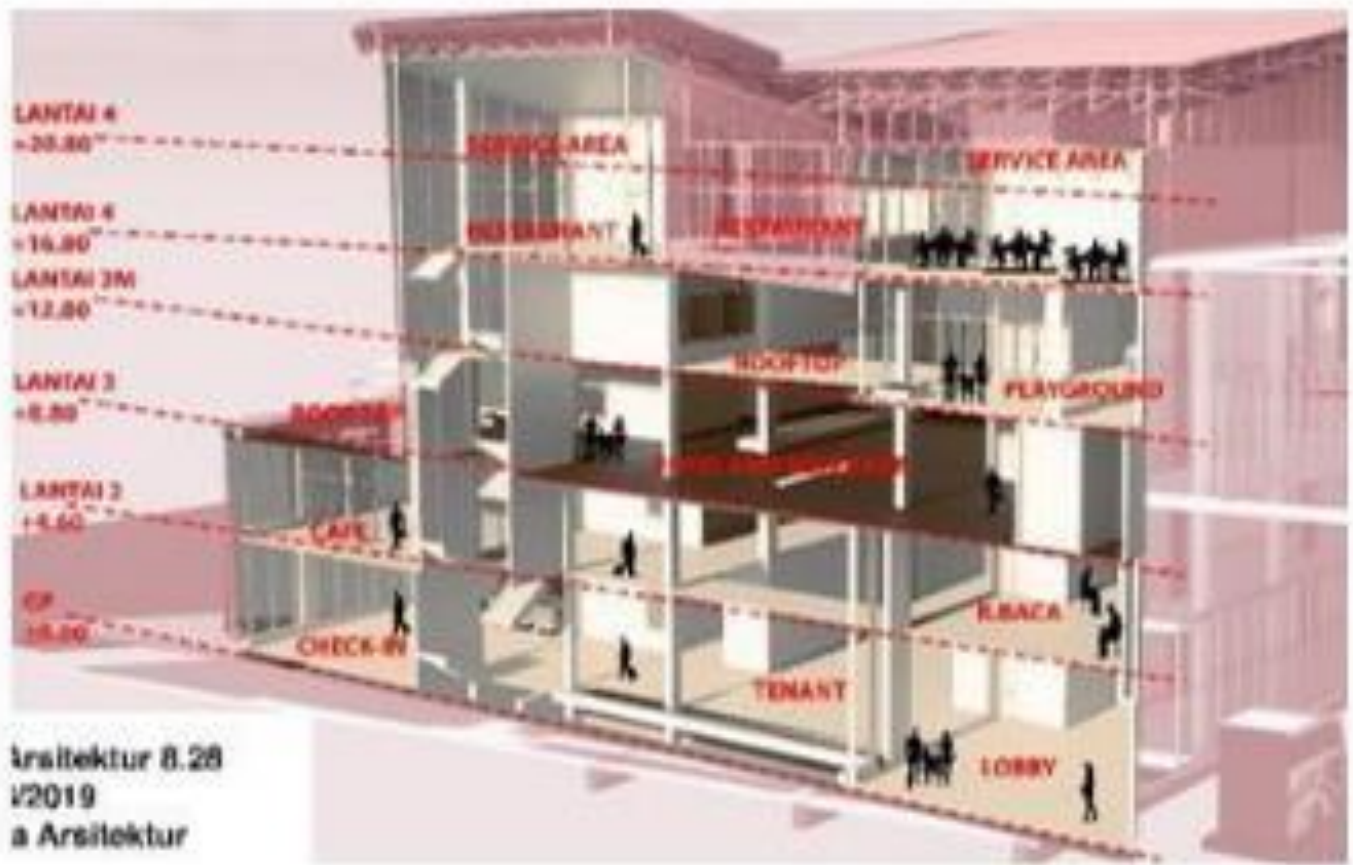

Gambar 14. Potongan Perspektif Bangunan Fasilitas Terminal Bus AKAP Rawa Buaya Sumber: Penulis, 2019

Selain itu, untuk memenuhi KDB, KLB, KDH, dan KB membentuk sirkulasi secara horizontal maupun vertikal yang membentung ruang dengan fungsi yang kontras sebagai fasilitas transit terminal rawa buaya, dimana fungsi pelayanan sebagai transit berada pada lantai dasar dan lantai dua, sedangkan lantai selanjutnya memiliki fungsi hiburan dan komersil seperti café, restaurant, playground, interactive stair, dan lain sebagainya yang dapat dilihat dari gambar dibawah ini.

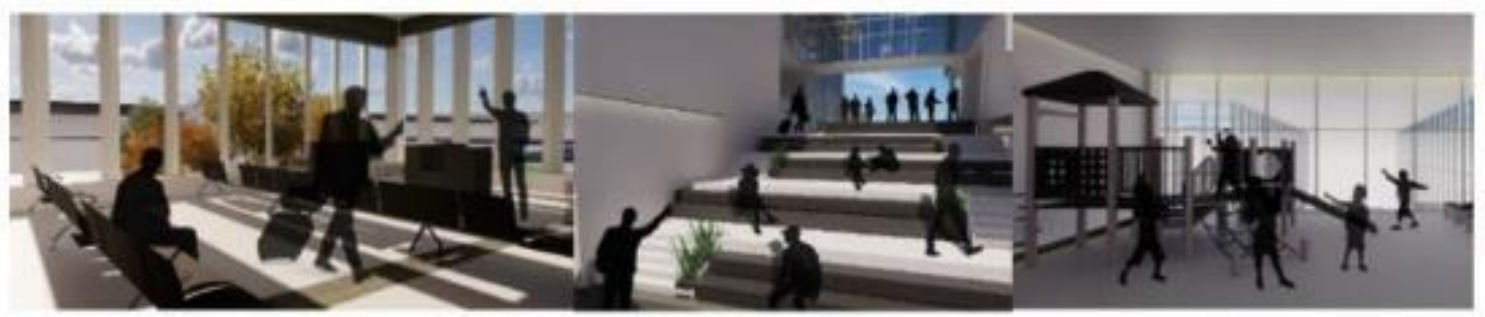

Gambar 15. Perspektif Interior Bangunan Fasilitas Terminal Bus AKAP Rawa Buaya Sumber: Penulis, 2019

\section{KESIMPULAN DAN SARAN}

Jakarta merupakan kota terpadat dengan zona yang kontras antara perumahan dan perkantoran. Zona ini mengakibatkan peningkatan perpindahan penduduk, kepemilikan kendaraan, dan moda transportasi, serta timbulnya batasan-batasan anatara lingkungan sosial. Peningkatan mobilitas yang tinggi dan perkembangan zaman yang terjadi menghasilkan pengertian lain dalam konsep Third Place. Third Place yang awalnya hanya sebagai ruang publik, ruang sosial, dan ruang interaksi dapat dirasakan bukan hanya pada pengunjung restoran atau café. Komunitas transportasi umum lebih merasakan konsep Third Place, dimana mereka dapat merasakan perbedaan zona perumahaan dengan zona perkantoran. Third Place juga dapat disebut sebagai tempat singgah yang dapat disebut juga sebagai area transit pada transportasi umum. Dengan adanya Fasilitas Transit Terminal Rawa Buaya diharapkan dapat digunakan oleh pengunjung Terminal Bus Rawa Buaya sebagai ruang sosial yang ada di kecematan Cengkareng. 


\section{REFERENSI}

Adhiatma, W., \& Christianto, L. P. (2019). Suara Psikologi: Untuk Insan Indonesia. Jakarta: Universitas Katolik Indonesia Atma Jaya.

Akcan, E. (2018). Open Architecture: Migration, Citizenship and the Urban. Basel: Birkhauser.

Kupriyanov, R., \& Zhdanov, R. (2014). The eustress concept: Problems and out looks. Nasib Tua Lumban Gaol, 1.

Moeljono, D. D. (2003). Budaya Korporat dan Keunggulan Korporasi. Jakarta: PT Elex Media Komputindo.

Montgomery, C. (2013). Happy City: Transforming Our Lives Through Urban Design. New York: Farrar, Straus and Giroux.

Munandar, U. (2009). Pengembangan Kreativitas anak berbakat. Jakarta: Rineka Cipta.

Myers, P. (2012). Going Home: Essays, Articles, and Stories in Honour of the Andersons. London: OAK HILL COLLEGE.

Oldenburg, R. (1999). The Great Good Place. US: Da Capo Press.

Perhubungan, D. (1996). Direktorat Jenderal Perhubungan Darat, "Pedoman Teknis Perakayasaan Tempat Perhentian Kendaraan Penumpang Umum". Jakarta: Departemen Perhubungan.

Ravenstein, E. G. (1976). The Laws of Migration. New York: Arno Press.

Sutiyoso. (2007). Megapolitan. Jakarta: PT Elex Media Komputindo.

Tom W, S., Jaesok, S., \& Benjamin, S. (2015). Trends in Pychological Well-Being 1972-2014. Chicago: NORC at the University of Chicago.

Tschumi, B. (2004). Event-cities 3: Concept Vs. Context Vs. Content. New York: MIT Press.

Waitz, G., Strømme, S., \& Railo, W. S. (1983). Conquer stress with Grete Waitz. Sukadiyanto, 56.

Badan Pusat Statistik Provinsi DKI Jakarta. (2017).

Jumlah Penduduk dan Rasio Jenis Kelamin Menurut Kabupaten Kota di Provinsi DKI Jakarta. https://jakarta.bps.go.id/statictable/2017/01/24/91/3-1-2-jumlah-pendudukdan-rasiojenis-kelamin-menurut-kabupaten-kota-di-provinsi-dki-jakarta2015.html. 16 Agustus 2019.

Liputan 6. (2017). Macet Warga Jakarta Habiskan Waktu di Jalan 22 Hari per Tahun. https://m.liputan6.com/citizen6/read/3152649/macet-warga-jakarta-habiskanwaktu-dijalan-22-hari-per-tahun. 20 Juli 2019.

Liputan 6. (2011). Jauhnya Jarak Rumah ke Kantor Pengaruhi Kesehatan https://m.liputan6.com/health/read/362375/jauhnya-jarak-rumah-ke-kantorpengaruhikesehatan. 20 Juli 2019.

Wikipedia. (2019). Third Place.

https://en.wikipedia.org/wiki/Third_place.16 Agustus 2019.

KBBI. (2016). Kreatif.

https://kbbi.web.id/kreatif. 28 Agustus 2019.

Wikipedia. (2017). Hiburan.

https://id.wikipedia.org/wiki/Hiburan. 22 Juli 2019.

Wikipedia. (2019). Cengkareng, Jakarta Barat https://id.wikipedia.org/wiki/Cengkareng,_Jakarta_Barat. 22 Juli 2019.

Portal Resmi Provinsi DKI Jakarta. (2017). Cengkareng Kecamatan. https://jakarta.go.id/artikel/konten/532/cengkareng-kecamatan. 22 Juli 2019. Portal Resmi Provinsi DKI Jakarta. (2017). Cengkareng Kecamatan. https://jakarta.go.id/artikel/konten/532/cengkareng-kecamatan. 22 Juli 2019.

Databoks Katadata. (2015). Cengkareng Kecamatan dengan Penduduk Paling Banyak di Jakarta.

https://jakarta.bps.go.id/statictable/2017/01/24/91/3-1-2-jumlah-penduduk-dan-rasio-jeniskelamin-menurut-kabupaten-kota-di-provinsi-dki-jakarta-2015.html diakses 16 Agustus 2019 
Wartakota. (2019). Terminal Tipe A akan Dibangun di Rawa Buaya Gantikan Terminal Kalideres. https://wartakota.tribunnews.com/2017/01/27/terminal-tipe-a-akan-dibangundi-rawabuaya-gantikan-terminal-kalideres. 22 Juli 2019.

Wikipedia. (2019). Duri Kosambi Cengkareng Jakarta Barat https://id.wikipedia.org/wiki/Duri_Kosambi,_Cengkareng,_Jakarta_Barat. 22 Juli 2019. 